\title{
TAPIOCA IN TAMILNADU-AN OVERVIEW
}

\section{K. ANITHA ${ }^{1} \&$ V. P. JAYALAKSHMI ${ }^{2}$}

${ }^{1}$ Research Scholar (Part-Time) in Economics, Government Arts College, Salem, India

${ }^{2}$ Associate Professor \& Head, Department of Economics, Government Arts College, Salem, India

\begin{abstract}
Tapioca is an important staple food crop and industrial crop in Asia, Africa, and Latin America. Because of its drought tolerance and wider adaptability to varied soil nutrient and agro-climatic conditions, resistance to the pests and diseases as well as high-calorie value, it has become a very important crop in these parts of the world. Tapioca is being grown in India for more than a century. Ever since the former rulers of Travancore encouraged the cultivation of tapioca in the $19^{\text {th }}$ century to overcome the rice shortages, tapioca cultivation has grown from strength to strength. Under area and production of tapioca in India, Tamilnadu holds the second position. This crop is being cultivated under both irrigated and rainfed conditions. It is cultivated and grown under irrigated conditions in the districts of Salem, Erode, Dharmapuri, and Namakkal. In the rest of the district, it is cultivated as the rainfed crop. This crop is cultivated as monocrop and also as intercrop. As an intercrop it is cultivated in coconut orchards. Under irrigated conditions, it is rotated with turmeric and paddy.

KEYWORDS: Staple Food, Overcome the Shortage, CTCRI Varieties, Methods of Cultivation \& Health Benefits
\end{abstract}

Received: Sep 20, 2018; Accepted: Oct 20, 2018; Published: Nov 01, 2018; Paper Id.: IJECRDEC20181

\section{INTRODUCTION}

Tapioca is an important staple food crop and industrial crop in Asia, Africa, and Latin America. Because of its drought tolerance and wider adaptability to varied soil nutrient and agro-climatic conditions, resistance to the pests and diseases as well as high-calorie value, it has become a very important crop in these parts of the world. Tapioca is being grown in India for more than a century. Ever since the former rulers of Travancore encouraged the cultivation of tapioca in the $19^{\text {th }}$ century to overcome the rice shortages, tapioca cultivation has grown from strength to strength.

Under area and production of tapioca in India, Tamilnadu holds the second position. This crop is being cultivated under both irrigated and rainfed conditions. It is cultivated and grown under irrigated conditions in the districts of Salem, Erode, Dharmapuri, and Namakkal. In the rest of the district, it is cultivated as the rainfed crop. This crop is cultivated as monocrop and also as intercrop. As an intercrop it is cultivated in coconut orchards. Under irrigated conditions, it is rotated with turmeric and paddy. Since 1976, the varieties of H-226 and H-165 which is released by CTCRI (Central Tuber Crop Research Institute) were cultivated more in Tamilnadu. These varieties occupy more than $70 \%$ of the area in cultivation. In addition to these varieties Mulluvadi, Burma, $\mathrm{CO} 2$, and Kumkumarose are cultivated in many areas. As tapioca is cultivated more for the industrial use they are largely grown by the marginal, medium and small size of farmers. As in the industrial area of Salem, these crops are cultivated by large farmers. 


\section{CULTIVATION METHOD}

\section{Land Preparation Method}

Tapioca is cultivated more in the black and red soils. The preparation of land is done with the help of bullock and tractor ploughs. Normally 15 to 20 days before planting, the land is ploughed nearly 5 to 6 times in an average with bullock or tractor ploughs. Using manual labor the unwanted grass and weeds are removed before the fourth ploughing activity. Finally, the manures are broadcasted in the field before the last plough. Before planting, the ridges, furrows, and channels are finally made.

\section{Making of Nursery}

Forming of the nursery is done for the crop under irrigated condition. This type of activity is mostly practiced in Salem, Namakkal, and Erode districts only. Whereas in the other districts direct planting method is adopted. Using the farm equipment's the setts are then prepared. These are made into six inches length pieces. These setts are then planted on the beds rised with closer spacing intervals and were sprinkled with water and finally, they were covered with palm leaves. The water is frequently given with an interval of 4-5 days till setts get ready for next process. After the arrival of the first leaf from the stem, the setts are planted within 15-20 days. This nursery practice is carried out in an area of 10 sq. $\mathrm{m}$ to 13.5 sq. $\mathrm{m}$, which is sufficient to transplant to the main field.

\section{Transplanting of Setts}

The setts which are rooted is planted at a spacing of either $75 \times 75 \mathrm{~cm}$ or $90 \times 90 \mathrm{~cm}$ between rows and between the plants in the main field. Later the setts are carefully planted at a depth of 7 to $8 \mathrm{~cm}$ vertically.

\section{Planting Season of the Crop}

This crop is cultivated both in rainfed as well as irrigated condition. Under the irrigated condition, this crop is cultivated in the month of December to February whereas as a rain fed, it is cultivated during the month of July to September.

\section{Fertilizers and Manures Used by the Farmers}

The farmers mainly apply superphosphate, potash, diammonium phosphate, and complex fertilizers. Towards weeding, these fertilizers were applied for twice or thrice split doses for basal or for the top. They were applied both under irrigated as well as under rainfed conditions indiscriminately by the farmers. After transplanting the setts to the main field these fertilizers are applied after 2 to 3 months at an interval of 15 to 20 days.

\section{Weeding as an Intercultural Operation}

Weeding practices are done both under irrigated and also under rain fed. In an average, seven to eight weeding may be carried out under irrigated cultivation whereas four to five weeding may be done under rainfed cultivation. This weeding practice is followed only by very few farmers because of its high cost of weedicides and lack of knowledge etc. this activity is repeated till 175 days after planting in the main field.

\section{Irrigation Method}

Based on the availability of moisture in the soil, irrigation is done 15 to 16 times for the growth of the crop. After transplanting the setts irrigation is given immediately of within in a week after planting, then frequently at 10 days 
intervals regularly for five months. During the time of land preparation, irrigation channels will be made. The major source of irrigation is groundwater.

\section{Pests and Diseases on Crop}

CMD (Cassava Mosaic Disease) and tuber rot are the major diseases of all other diseases for the crop. Some farmers apply Bavistin to control it, but many do not apply any control measures. Recently, the spirally whitefly insect is affecting the crops.

\section{Stage of Harvesting}

Irrigation is done before harvest so that the tubers can be easily lifted. Contract labors are also engaged in this job. On an average irrigated crop is yielding 38 tonnes per hectare while under rainfed, yield ranges from 20 to 25 tonnes per hectare. A crop can be harvested from $8^{\text {th }}$ month onwards based on the variety planted.

\section{Storage}

After the process of harvest, it is the time to store the planting materials it is said that they can be stored under shade only for a maximum of 3 months. No chemical is induced for this process. It was also said that these materials loss up to a ten percentage during storage. Finally, they were covered with palm leaves.

\section{BENEFITS OF TAPIOCA}

Some of the health benefits of tapioca are as follows

- Consuming of tapioca gives a solution to the people suffering from the celiac disease which is a type of allergy, where the people cannot digest the gluten.

- Tapioca can be consumed in moderate amount as it is a cholesterol free food.

- Since tapioca consists of carbohydrate and unsaturated fat it helps in healthy weight gain for the people who are underweight.

- It also helps in the reduction of blood pressure and tension, which in turn supports the reduction in the risk of heart disease.

- For the women suffering in anemia during pregnancy can consume tapioca as it is rich in nutrients.

- Tapioca helps in the prevention of anemia or red blood cells deficiency in the body.

- As tapioca contains a high amount of carbohydrate, it acts as a boosted metabolism.

- Tapioca is a rich source of vitamin $\mathrm{K}$, iron and calcium and so it helps in the development of bones.

\section{CONCLUSIONS}

Tapioca as a storehouse of energy and starch is tending to be ideal for processing into a large number of value-added products. With the fast increasing population of India, it is expected that the population would reach 1.5 billion by the year of 2020 . Hence it is forecasted that there would be a shortage of food grains in the future. It is estimated that tuber crops like tapioca would help in meeting out the shortage by expanding its cultivation in future. 


\section{REFERENCES}

1. Ahok Gupta (1990), Green book on tapioca, The Sago Serve 1990.

2. Collins and Holton (1998), "Marketing of agricultural produce", Vishwaprakasham, A division of new agricultural international private limited publishers, pp.302.

3. Christy. A.E, (1996), “Micropropogation in Tapioca”, Green book on Tapioca, Sago Serve, Vol.2.

4. Edison. S etal (2006), "Status of Cassava in India an overall view", CTCRI, November.

5. Srinivas. T (2005), “Cassava marketing system in India”, CTCRI, December. 